\title{
THE EFFECTS OF HYALURONIC ACID, CALCIUM HYDROXIDE, AND DENTIN ADHESIVE ON RAT ODONTOBLASTS AND FIBROBLASTS
}

\author{
Ana BOGOVIĆ ${ }^{1}$, Jana NIŽETIĆ ${ }^{1}$, Nada GALIĆ ${ }^{1}$, Davor ŽELJEŽIĆ ${ }^{2}$, Vedran MICEK ${ }^{2}$, \\ and Marin MLADINIĆ ${ }^{2}$ \\ University of Zagreb School of Dental Medicine ${ }^{1}$, Institute for Medical Research and Occupational Health ${ }^{2}$, \\ Zagreb, Croatia
}

Received in September 2010

CrossChecked in October 2010

Accepted in April 2011

\begin{abstract}
The aim of this study was to investigate the effects and efficiency of pulp capping preparations based on hyaluronic acid, calcium hydroxide, and dentin adhesive on the pulp tissue of Sprague-Dawley rats. The rats were killed and extracted teeth sectioned transversely through the pulp. The slices were placed in a RPMI 1640 cell culture medium supplemented with $10 \%$ foetal calf serum. During 14 days of cultivation cultures were treated with preparations that contained hyaluronic acid (Gengigel Prof ${ }^{\circledR}$ ), and calcium hydroxide $\left(\mathrm{ApexCal}^{\circledR}\right)$, or with dentin adhesive $\left(\right.$ Excite $\left.^{\circledR}\right)$. Cellularity and viability of fibroblasts and odontoblasts was analysed using a haemocytometer. Hyaluronic acid proved most efficient and the least toxic for direct pulp capping. Even though calcium hydroxide and dentin adhesive demonstrated a higher degree of cytotoxicity, their effects were still acceptable in terms of biocompatibility.
\end{abstract}

KEY WORDS: direct pulp capping, fibroblast proliferation, odontoblastic proliferation

Maintaining the vitality of dental pulp has been one of the fundamental concepts of dental treatment for a long time. If the pulp chamber is exposed, it is usually treated by direct capping. The procedure relies on the ability of the dentin-pulp complex to repair dentin (1-5).

The dental pulp is a highly vascular connective tissue. Generally, pulp cells can be divided into formative and protective cells. Formative cells are odontoblasts and fibroblasts, and protective cells are macrophages, lymphocytes, mastocytes, lymphoid cells, pericytes, and undifferentiated cells $(1,6)$. Odontoblasts are responsible for dentinogenesis. They are post-mitotic cells which, once differentiated, can no longer divide and can only be replenished from cells from the subodontoblastic layer (7). Fibroblasts are the most common pulp cells. They are responsible for secreting ground substance and collagen (1).

Products most often used for pulp capping are calcium hydroxide-based materials, glass ionomer cements, adhesive systems, and mineral trioxide aggregates (8-11).

Calcium hydroxide is the most common material for direct capping of exposed pulp (8). Due to its alkalinity, it has a bactericidal effect and stimulates the formation of reparative dentin. It causes sterile necrosis of the pulp tissue (2). Its main drawbacks are the risk of dystrophic calcification, of discontinuous dentin bridge with the so called "tunnel defects", of overaggressive caustic effect on the pulp, and of internal root resorption (12). 
The main advantage of dentin adhesives is they bond with the dentin tightly to minimise bacterial penetration into the damaged pulp (13). In vitro and in vivo studies (14-19) have demonstrated that the cytotoxic effects of adhesives depend on the amount ofnon-polymerised resin monomers. Many components of the adhesive systems and resin composites such as bisphenol A-glycidyl methacrylate (Bis-GMA), urethane dimethacrylate (UDMA), triethylene glycol dimethacrylate (TEGDMA), 2-hydroxyethyl methacrylate (HEMA), and camphorquinone are cytotoxic to directly exposed mammalian fibroblasts (20-22).

Since neither calcium hydroxide nor adhesives can fully preserve the vitality of the exposed pulp, new materials are studied to replace them $(21,23,24)$. Hyaluronic acid (HA) has recently emerged as a material of choice in preserving the vitality of the pulp. It is a natural mucopolysaccharide, carbohydrate polymer from the group of glycosaminoglycans. HA is synthetised on the cytoplasmatic surface of plasma membranes $(25$, 26 ) and is common in humans and other vertebrates. It is the major component of the inner-cell cement, of the capillary wall, and of the extracellular matrix of the connective tissue (27). Deposition of HA significantly increases during development, morphogenesis, wound repair and regeneration, malignancy, and inflammation $(26,28,29)$.

The aim of this study was to investigate the effects of HA on the proliferation of odontoblasts and fibroblasts and to assess its potential as a material for direct pulp capping in humans. For comparison, we also assessed the effects of calcium hydroxide and of one of commonly used dentin adhesives.

\section{MATERIALS AND METHODS}

\section{Materials}

In this study we tested three preparations used in dental medicine: (1) calcium hydroxide preparation (ApexCal ${ }^{\circledR}$, Ivoclar Vivadent, Liechtenstein), which is composed of calcium hydroxide, bismuth carbonate, polyethylene glycol, glycerine, and water; (2) dentin adhesive (Excite ${ }^{\circledR}$, Ivoclar Vivadent, Liechtenstein), which is composed of phosphonic acid acrylate, hydroxyethyl methacrylate, dimethacrylate, highly dispersed silica, ethanol, catalysts, stabilizers, and fluoride; and (3) hyaluronic acid gingival gel (Gengigel
Prof ${ }^{\circledR}$, Ricerfarma Srl, Italy), which contains purified water, xylitol, cellulose gum, alcohol, sodium hyaluronate, PEG-40 hydrogenated castor oil, polyvinyl alcohol, polycarbophil, and dichlorobenzyl alcohol.

\section{Methods}

The study was performed on the cells isolated from two male and two female adult Sprague-Dawley rats, weighing $200 \mathrm{~g}$ to $400 \mathrm{~g}$. The animals were euthanised with $\mathrm{CO}_{2}$ in a glass air-tight chamber (Tlos, Croatia). The incisor teeth were extracted and immediately immersed in cold $\left(3^{\circ} \mathrm{C}\right.$ to $\left.5{ }^{\circ} \mathrm{C}\right)$ buffer containing $140 \mathrm{mmol} \mathrm{L}^{-1} \mathrm{NaCl}$ (Kemika, Croatia), $3 \mathrm{mmol} \mathrm{L}^{-1}$ $\mathrm{KCl}$ (Kemika, Croatia), $1 \mathrm{mmol} \mathrm{L}^{-1} \mathrm{CaCl}_{2}$ (Kemika, Croatia), $1 \mathrm{mmol} \mathrm{L}^{-1} \mathrm{MgCl}_{2}$ (Kemika, Croatia), and $10 \mathrm{mmol} \mathrm{L}^{-1}$ HEPES (Sigma-Aldrich, USA) whose $\mathrm{pH}$ was 7.3 to 7.4 (adjusted with $\mathrm{NaOH}$ ). After all the connective tissue, bone and blood that adhered to the outer surface of the tooth were removed carefully with a small piece of sterile gauze. The crown was then sliced transversally through the pulp using an ISOMET low-speed saw (Buehler, Lake Bluff, USA) at $100 \mathrm{rpm}$. The slices were then collected with a forceps one by one and incubated for $15 \mathrm{~min}$ at $35^{\circ} \mathrm{C}$ in an extracellular solution supplemented with $3 \mathrm{mg} \mathrm{mL}^{-1}$ collagenase and $0.25 \mathrm{mg} \mathrm{mL}^{-1}$ protease (SigmaAldrich, USA). After incubation, the suspension was centrifuged at $600 \mathrm{rpm}$ for $10 \mathrm{~min}$, the supernatant removed, and the remaining slices and isolated cells cultured in plastic, $25 \mathrm{~cm}^{2}$ Falcon culture flasks with a vented cap (BD Biosciences, USA). Into each flask we added 5 mL RPMI 1640 (Gibco, UK), 1000 IU of streptomycin, $1000 \mathrm{IU}$ of penicillin, $25 \mu \mathrm{g} \mathrm{mL}^{-1}$ of chloramphenicol (Sigma-Aldrich, USA) and $1.4 \mathrm{~mL}$ of fetal bovine serum (Gibco, UK). In total, four cell cultures were cultivated. In order for the cells to adjust to in vitro conditions, the treatment started four days after the cultivation began. We added $2 \mathrm{~mm}^{2}$ of polymerised dentin adhesive $\left(\right.$ Excite $\left.^{\circledR}\right)$ into the first culture, $2 \mathrm{~mm}^{2}$ of solid calcium hydroxide preparation $\left(\right.$ ApexCal $\left.{ }^{\circledR}\right)$ into the second, $0.1 \mathrm{~mL}$ of HA preparation $\left(\right.$ Gengigel Prof $\left.^{\circledR}\right)$ into the third, while the fourth culture served as control. The cultures were kept at $37{ }^{\circ} \mathrm{C}$ in an atmosphere of $5 \% \mathrm{CO}_{2}$. Every four days the cultures were transferred into sterile plastic test tubes with plastic caps (Greiner Bio-One, Germany) and centrifuged at $600 \mathrm{rpm}$ for 10 minutes. Supernatant was removed to $1 \mathrm{~mL}$, the sediment of cells was resuspended and put back into the culture of the same nutritive value as the initial culture. After each change 
of the nutritive medium, the cultures were re-treated with the capping preparations. The treatment lasted 14 days, after which the cultures were centrifuged at $600 \mathrm{rpm}$ for 10 minutes, and supernatant removed to $1 \mathrm{~mL}$. The sediment was resuspended and cell number and viability assessed.

\section{Cell counting}

A cover slip was attached to the Bürker-Türk chamber. Pasteur's pipette with a pointed tip was used to put a drop of cell suspension along the rim of a cover slip next to the engraved net. Cell count included all cells in four corner squares and those found on its two neighbouring sides. Square dimensions were $1 \mathrm{~mm} \times 1 \mathrm{~mm}$ and $0.1 \mathrm{~mm}$ high. This makes the volume of $0.1 \mathrm{~mm}^{3}(0.1 \mu \mathrm{L})$. In order to calculate the number of cells per millilitre of a culture, cell counts were multiplied by 10,000 . Odontoblasts and fibroblasts were counted separately. Cellularity was determined for each culture in triplicate and presented as an arithmetic mean and standard deviation.

\section{Viability assessment}

Fifty microlitres of cell suspension was placed on a microscope slide and dyed with $50 \mu \mathrm{L}$ of solution that contained acridine orange $\left(100 \mathrm{mg} \mathrm{mL}^{-1}\right.$; SigmaAldrich, USA) and ethidium bromide $\left(100 \mu \mathrm{g} \mathrm{mL}^{-1}\right.$; Sigma-Aldrich, USA). Specimens were then covered with a cover slip and analysed with an epifluorescent microscope Olympus AX70 (Olympus, Japan). The analysis included 50 fibroblasts and 50 odontoblasts for each culture. Differences in staining made it possible to count apoptotic cells (condensed chromatin was visible) and necrotic cells (red fluorescent cells) (30). Viability assessment was repeated for each culture in triplicate and presented as an arithmetic mean and standard deviation.

\section{Statistical analysis}

The findings were analysed using the chi-square test. The level of $p<0.05$ was considered significant.

\section{RESULTS AND DISCUSSION}

In comparison with the control culture, the number of fibroblasts and odontoblasts was greater in the culture treated with HA and smaller in cultures treated with calcium hydroxide and dentin adhesive, but not significantly (Table 1).

Table 1 Cell count in cultures by dental capping material.

\begin{tabular}{lcccc}
\hline \multirow{2}{*}{ Cell type } & \multicolumn{3}{c}{ Treatment } \\
\cline { 2 - 5 } & Control & $\begin{array}{c}\text { Hyaluronic acid } \\
(\text { Gengigel Prof }\end{array}$ & $\begin{array}{c}\text { Dentin adhesive } \\
\left(\text { Excite }^{\circledR}\right)\end{array}$ & $\begin{array}{c}\text { Calcium hydroxide } \\
\left(\text { ApexCal }^{\circledR}\right)\end{array}$ \\
\hline Fibroblasts & $200.7 \pm 14.0$ & $226.0 \pm 23.5$ & $176.7 \pm 18.1$ & $163.7 \pm 12.6^{*}$ \\
\hline Odontoblasts & $92.7 \pm 6.6$ & $113.3 \pm 13.9$ & $79.0 \pm 17.5$ & $78.7 \pm 14.5$ \\
\hline
\end{tabular}

Data are expressed as mean cell number per milliliter of culture $\pm S D$ ${ }^{*} p<0.05$

Table 2 Cell viability in culture by dental capping material

\begin{tabular}{|c|c|c|c|c|c|}
\hline \multirow[b]{2}{*}{ Cell type } & \multirow[b]{2}{*}{ Viability } & \multicolumn{4}{|c|}{ Treatment } \\
\hline & & Control & $\begin{array}{l}\text { Hyaluronic acid } \\
\left.\text { (Gengigel Prof }^{\circledR}\right)\end{array}$ & $\begin{array}{l}\text { Dentin adhesive } \\
\left.\text { (Excite }{ }^{\circledR}\right)\end{array}$ & $\begin{array}{c}\text { Calcium hydroxide } \\
\left(\text { ApexCal }^{\circledR}\right)\end{array}$ \\
\hline \multirow{3}{*}{ Fibroblasts } & Viable & $46.3 \pm 2.1$ & $41.3 \pm 1.2$ & $36.3 \pm 3.8^{*}$ & $32.3 \pm 3.1^{*}$ \\
\hline & Apoptosis & $3.3 \pm 1.5$ & $6.3 \pm 1.2$ & $10.7 \pm 2.1^{*}$ & $14.0 \pm 1.7^{*}$ \\
\hline & Necrosis & $0.3 \pm 0.6$ & $2.3 \pm 1.2$ & $3.0 \pm 1.7$ & $3.7 \pm 4.7$ \\
\hline \multirow{3}{*}{ Odontoblasts } & Viable & $45.3 \pm 1.5$ & $44.3 \pm 3.2$ & $33.0 \pm 1.7^{* *}$ & $37.3 \pm 1.2$ \\
\hline & Apoptosis & $4.7 \pm 1.5$ & $4.3 \pm 2.1$ & $12.0 \pm 2.6^{* *}$ & $10.3 \pm 1.5$ \\
\hline & Necrosis & $0.0 \pm 0.0$ & $1.3 \pm 1.2$ & $5.0 \pm 2.0$ & $2.7 \pm 1.5$ \\
\hline
\end{tabular}

Data are expressed as \% of cells $\pm S D$

${ }^{*} p<0.05$

${ }^{* *} p<0.01$ 
Viability was also higher in the culture treated with HA and smaller in those treated with calcium hydroxide and dentin adhesive (Table 2).

In contrast, the number of apoptotic and necrotic cells was smaller in the culture treated with HA than in control. Cultures treated with dentin adhesive had a greater number of odontoblasts affected by apoptosis and necrosis, and those treated with calcium hydroxide had a greater number of fibroblasts affected by apoptosis and necrosis.

Our results demonstrate high therapeutic efficiency of HA in direct pulp capping. They also confirm the efficiency of calcium hydroxide and dentin adhesives $(12,31)$. The mechanism by which calcium hydroxide initiates the reparative process is unclear. Tronstadt et al. (32) suggest that free hydroxyl ions raise $\mathrm{pH}$, which stimulates mineralisation (32). In that way calcium hydroxide neutralises the acidic reaction of the inflamed tissue, which is characteristic of cariesaffected dentin (33). The first effect of calcium hydroxide on exposed pulp is the development of a superficial, three-layer necrosis $(2,34)$. This could explain the large number of apoptotic and necrotic cells found in our study. The mesenchymal and endothelial pulp cells adjoining the necrosis zone start to coagulate. Before mitosis they synthetised nuclear DNA, which resulted with an increased number of cells. Another result is the intensified synthesis of collagen at the periphery of the cells (35-37). When the pulp is protected from irritation, new odontoblasts can differentiate (2). Calcium hydroxide has a dentinogenic effect only when it is applied at the periphery of the pulp. It has been proven that placing calcium hydroxide in the central part of the pulp does not lead to the formation of the hard dentin tissue. It seems that the ability of calcium hydroxide to stimulate dentinogenesis is closely related to the presence of dentin and odontoblasts (38).

Although some very encouraging findings have been published $(39,40)$, it seems that dental adhesives may be too toxic for direct pulp capping $(14-19,41)$, as due to their water solubility they gradually release potentially toxic resin components: HEMA and TEGDMA. Both of them are capable to induce apoptosis or necrosis in normal human primary cells. Spagnuolo et al. (42) found time- and concentrationdependent apoptotic effects of TEGDMA on human pulp fibroblasts and predominantly apoptotic effects of HEMA on human skin fibroblasts (43). Their cytotoxicity depends on dentin permeability and duration of perfusion. The dentin with high permeability allows greater penetration of dentin adhesive and/or its components (40).

Our results on cell count in the culture treated with dentin adhesive have shown a drop in the number of fibroblasts and odontoblasts compared to the control culture. Cell viability was also lower. The number of apoptotic and necrotic cells was higher and odontoblasts were more affected than fibroblasts. However, the cytotoxicity of the dentin adhesive observed on fibroblasts and odontoblasts was lower than that of calcium hydroxide.

Hyaluronic acid seems to stimulate tissue vascularization, probably through direct action on endothelial cells $(44,45)$. Indirectly, it creates conditions favoring mineralisation. It stimulates migration of different cell types into the injured area and their proliferation and differentiation into odontoblast-like cells (46). We have shown that the culture treated with HA had an even greater number of odontoblasts and fibroblasts than the control culture, which indicates a great potential of this material for creating reparative dentin. In cultures treated with HA we found a smaller proportion of apoptotic and necrotic cells. Viability analysis has also shown that HA is less toxic and therefore more biocompatible with pulp than dentin adhesive and calcium hydroxide.

Taken together, our results show that all tested materials have a satisfactory degree of biocompatibility. However, as HA was more efficient than either of the traditionally used materials, its administration for direct pulp capping could be advised, especially because it is also safer to use.

\section{REFERENCES}

1. Walton RE, Torabinejad M. Principles and Practice of Endodontics. Philadelphia: W.B. Saunders Co.; 2002.

2. Schröder U. Effect of calcium hydroxide-containing pulpcapping agents on pulp cell migration, proliferation, and differentiation. J Dent Res 1985;64(Special No):541-8.

3. Tziafas D. Mechanisms controlling secondary initiation of dentinogenesis: a review. Int Endod J 1994;27:61-74.

4. Gala-Garcia A, Teixeira KI, Wykrota FH, Sinisterra RD, Cortés ME. Bioceramic/poly (glycolic)-poly (lactic acid) composite induces mineralized barrier after direct capping of rat tooth pulp tissue. Braz Oral Res 2010;24:8-14.

5. Chan C, Lan W, Chang M, Chen Y, Lan W, Chang H, Jeng JH. Effects of TGF- $\beta$ s on the growth, collagen synthesis and collagen lattice contraction of human dental pulp fibroblasts in vitro. Arch Oral Biol 2005;50:469-79. 
6. Kim JK, Shukla R, Casagrande L, Sedgley C, Nör JE, Baker JR Jr, Hill EE. Differentiating dental pulp cells via RGDdendrimer conjugates. J Dent Res 2010;89:1433-8.

7. Bränström M, Garberoglio R. The dentinal tubules and the odontoblast processes. A scanning electron microscopic study. Acta Odontol Scand 1972;30:291-311.

8. Modena KC, Casas-Apayco LC, Atta MT, Costa CA, Hebling J, Sipert CR, Navarro MF, Santos CF. Cytotoxicity and biocompatibility of direct and indirect pulp capping materials. J Appl Oral Sci 2009;17:544-54.

9. Parolia A, Kundabala M, Rao NN, Acharya SR, Agrawal P, Mohan M, Thomas M. A comparative histological analysis of human pulp following direct pulp capping with Propolis, mineral trioxide aggregate and Dycal. Aust Dent J 2010;55:59-64

10. da Silva LA, de Freitas AC, de Carvalho FK, de Querioz AM, Nelson-Filho P, Porto-Neto ST. Direct pulp capping with a self-etching adhesive system: histopathologic evaluation in dogs' teeth. Oral Surg Oral Med Oral Pathol Oral Radiol Endod 2009;108:e34-e40.

11. Shayegan A, Petein M, Vanden Abbeele A. The use of betatricalcium phosphate, white MTA, white Portland cement and calcium hydroxide for direct pulp capping of primary pig teeth. Dent Traumatol 2009;25:413-9.

12. Pitt Ford TR, Roberts GJ. Immediate and delayed direct pulp capping with the use of a new visible light-cured calcium hydroxide preparation. Oral Surg Oral Med Oral Pathol 1991;71:338-42.

13. Zanchi CH, Lund RG, Perrone LR, Ribeiro GA, del Pino FA, Pinto MB, Demarco FF. Microtensile bond strength of twostep etch-and-rinse adhesive systems on sound and artificial caries-affected dentin. Am J Dent 2010;23:152-6.

14. Rodrigues Accorinte M de L, Loguercio AD, Reis A, Muench A, Araújo VC. Adverse effects of human pulps after direct pulp capping with the different components from a total-etch three-step adhesive system. Dent Mater 2005;21:599-607.

15. Moraes Porto ICC, Andrade AK, Guēnes GM, Ribeiro AI, Braz R, Castro CM. In vitro potential cytotoxicity of an adhesive system to alveolar macrophages. Braz Dent J 2009;20:195-200.

16. Franz A, König F, Lucas T, Watts DC, Schedle A. Cytotoxicity effects of dental bonding substances as a function of degree of conversion. Dent Mater 2009;25:232-9.

17. Çetingüç A, Ölmez S, Vural N. HEMA diffusion from dentin bonding agents in young and old primary molars in vitro. Dent Mater 2007;23:302-7.

18. Huang FM, Chang YC. Cytotoxicity of dentine-bonding agents on human pulp cells in vitro. Int Endod J 2002;35:9059.

19. Mantellini MG, Botero TM, Yaman P, Dennison JB, Hanks CT, Nor JE. Adhesive resin induces apoptosis and cell-cycle arrest of pulp cells. J Dent Res 2003;82:592-6.

20. Becher R, Kopperud HM, Al RH, Samuelsen JT, Morisbak E, Dahlman HJ, Lilleaas EM, Dahl JE. Pattern of cell death after in vitro exposure to GDMA, TEGDMA, HEMA and two compomer extracts. Dent Mater 2006;22:630-40.

21. Paranjpe A, Zhang H, Johnson JD. Effects of mineral trioxide aggregate on human dental pulp cells after pulp-capping procedures. J Endod 2010;36:1042-7.

22. Hanks CT, Strawn SE, Wataha JC, Craig RG. Cytotoxic effects of resin components on cultured mammalian fibroblasts. J Dent Res 1991;70:1450-5.
23. Kiba W, Imazato S, Takahashi Y, Yoshioka S, Ebisu S, Nakano T. Efficacy of polyphasic calcium phosphates as a direct pulp capping material. J Dent 2010;38:828-37.

24. Huang GT-J, Takayoshi Y, Shea LD, Djouad F, Nastaran ZK, Tuan RS, Shi S. Stem/Progenitor cell-mediated de novo regeneration of dental pulp with newly deposited continuous layer of dentin in an in vivo model. Tissue Engin A 2010;16:605-15.

25. Weigel PH, Hascall VC, Tammi M. Hyaluronan synthases. J Biol Chem 1997;272:13997-14000.

26. Toole BP, Hascall VC. Hyaluronan and tumor growth. Am J Pathol 2002;161:745-7.

27. Kennedy JF, Phillips GO, Williams PA, Hascall VC, editors. Hyaluronan. $1^{\text {st }}$ ed. Cambridge: Woodhead Publishing Ltd; 2002.

28. de la Motte C, Nigro J, Vasanji A, Rho H, Kessler S, Bandyopadhyay S, Danese S, Fiocchi C, Stern R. Plateletderived hyaluronidase 2 cleaves hyaluronan into fragments that trigger monocyte-mediated production of proinflammatory cytokines. Am J Pathol 2009;174:2254-64.

29. Volpi N, Schiller J, Stern R, Soltés L. Role, metabolism, chemical modifications and applications of hyaluronan. Curr Med Chem 2009; 16:1718-45.

30. Duke RC, Cohen JJ. Morphological and biochemical assays of apoptosis. In: Coligan JE, Kruisbeak AM, editors. Current protocols in immunology. New York (NY): John Wiley \& Sonds; 1992. p. 3.17.1-16.

31. Kostoryz EL, Eick JD, Chappelow CC, Glaros AG, Wetmore L, Yourtee DM. In vitro effect of light-cure dental adhesive on IL-6 release from LPS- stimulated and unstimulated macrophages. J Biomed Mater Res 2003;65:89-94.

32. Tronstad L, Andreasen JO, Hasselgren G, Kristerson L, Riis I. $\mathrm{pH}$ changes in dental tissues after root canal filling with calcium hydroxide. J Endod 1981;7:17-21.

33. Heithersay GS. Calcium hydroxide in the treatment of pulpless teeth with associated pathology. J Brit Endod Soc 1975;8:74-93.

34. Schröder U, Granath LE. Early reaction of intact human teeth to calcium hydroxide following experimental pulpotomy and its significance to the development of hard tissue barrier. Odont Revy 1971;22:379-95.

35. Uitto VJ, Antila R, Ranta R. Effects of topical glucocorticoid medication on collagen biosynthesis in the dental pulp. Acta Odontol Scand 1975;33:287-98.

36. Fitzgerald M. Cellular mechanisms of dentinal bridge repair using ${ }^{3} \mathrm{H}$-thimidine. J Dent Res 1979;58:2198-206.

37. Torneck CD, Moe H, Howley TP. The effect of calcium hydroxide solution on porcine pulp fibroblasts in vitro. $\mathrm{J}$ Endod 1983;9:131-6.

38. Tziafas D, Veis A, Alvanou A. Inability of calcium hydroxide to induce reparative dentinogenesis at non-peripheral sites of dog dental pulp. Eur J Oral Sci 1996;104:623-6.

39. Pereira JC, Segala AD, Costa CA. Human pulpal response to direct pulp capping with an adhesive system. Am J Dent 2000;13:139-47.

40. Wiegand $\mathrm{A}$, Buchholz $\mathrm{K}$, Werner $\mathrm{C}$, Attin $\mathrm{T}$. In vitro cytotoxicity of different desensitizers under simulated pulpal flow conditions. J Adhes Dent 2008;10:227-32.

41. Demirci M, Hiller KA, Bosi C, Galler K, Schmalz G, Schweikl H. The induction of oxidative stress, cytotoxicity, and genotoxicity by dental adhesives. Dent Mater 2008;24:362-71. 
42. Spagnuolo G, Galler K, Schmalz G, Cosentino C, Rengo S, Schweikl H. Inhibition of phosphatdylinositol 3-kinase amplifies TEGDMA- induced apoptosis in primary human pulp cells. J Dent Res 2004;83:703-7.

43. Spagnuolo G, Mauro C, Leonardi A, Santilo M, Paterno R, Schweikl H, Avvedimento EV, Rengo S. NF-kappaB protetction against apoptosis induced by HEMA. J Dent Res 2004;83:837-42.

44. West DC, Kumar S. Hyaluronan and angiogenesis. In: Evered D, Whelan J, editors. Ciba Foundation Symposium 143 - The
Biology of Hyaluronan. New York (NY): John Wiley \& Sons Ltd.; 1989. p. 187-201.

45. Stern R, Asari AA, Sugahara KN. Size-specific fragments of hyaluronan: an information-rich system. Eur J Cell Biol 2006;85:699-715

46. Sasaki T, Kawamata-Kido H. Providing an environment for reparative dentine induction in amputated rat molar pulp by high molecular-weight hyaluronic acid. Arch Oral Biol 1995;40:209-19. 


\section{Sažetak \\ UTJECAJ HIJALURONSKE KISELINE, KALCIJEVA HIDROKSIDA I DENTINSKIH ADHEZIVA NA ODONTOBLASTE I FIBROBLASTE ŠTAKORA}

Cilj ovog rada bio je istražiti djelovanje preparata na bazi hijaluronske kiseline i kalcijeva hidroksida te dentinskog adheziva na pulpno tkivo Sprague-Dawley štakora u svrhu procjene učinkovitosti navedenih materijala kod direktnog prekrivanja pulpe. Izvađeni zubi transverzalno su podijeljeni kroz pulpu. Naresci su uzgajani u RPMI 1640 staničnom mediju obogaćenom s $10 \%$ fetalnoga telećeg seruma u plastičnim bočicama za staničnu kulturu. Kulture su tijekom 14 dana tretirane preparatima s hijaluronskom kiselinom $\left(\right.$ Gengigel Prof $\left.{ }^{\circledR}\right)$, kalcijevim hidroksidom $\left(\right.$ ApexCal $\left.{ }^{\circledR}\right)$ i dentinskim adhezivom (Excite ${ }^{\circledR}$ ). Nakon 14 dana pristupilo se analizi staničnosti i vijabilnosti s pomoću hemocitometra. Iako su preparati na bazi kalcijeva hidroksida i dentinski adheziv pokazali nešto viši stupanj citotoksičnosti, dobiveni su rezultati u granicama biokompatibilnosti. Primjena preparata na bazi hijaluronske kiseline postigla je najbolje rezultate te se ovaj materijal pokazao najboljim za direktno prekrivanje pulpe između tri ispitivana preparata.

KLJUČNE RIJEČI: direktno prekrivanje pulpe, proliferacija fibroblasta, proliferacija odontoblasta

\section{CORRESPONDING AUTHOR:}

Professor Nada Galić

University of Zagreb, School of Dental Medicine

Department for Endodontics and Restorative Stomatology

Gundulićeva 5, 10000 Zagreb, Croatia

E-mail:ngalic@sfzg.hr 